UDC 331

\title{
THE PRIORITY OF CYCLISTS SAFETY FACILITIES IN SURABAYA
}

\author{
Wijaya Nika Devi Permata \\ Master Program, Department of Civil Engineering, Faculty of Engineering, \\ University of Brawijaya, Indonesia
}

\author{
Arifin M. Zainul \\ Department of Civil Engineering, Faculty of Engineering, University of Brawijaya, Indonesia
}

\author{
Agustin Imma Widyawati \\ Department of Regional and City Planning, Faculty of Engineering, \\ University of Brawijaya, Indonesia \\ *E-mail: nikadevi.pw@gmail.com
}

\begin{abstract}
The complex transportation problems are often felt by big cities like Surabaya. Not just the problem of severe traffic congestion, air pollution and noise pollution are increasingly felt in addition to the bigger number of accidents. By that, to reduce the problems that occur, especially to reduce the number of accidents on the highway, an implementation of environmentally sustainable transport with restrictions on motor vehicles is needed to be done. This can be realized by encouraging more effective, healthy, and eco-friendly transportation modes such as bicycles. However, the physical characteristics of a bicycle that are different from other vehicle characteristics require more security levels. Therefore, we need an alternative preparation of safety priorities for cyclists in Surabaya which is expected to improve the security and safety of its users. The data collection in this study consists of collecting primary data in the form of interviews and distribution of questionnaires to respondents who are considered capable and skillful in the field. The number of respondents in this study amounted to 10 people from the Department of Transportation, Directorate General of Bina Marga of Public Works Department, Police Department, and Education Department in Surabaya. The analytical method used in this research is Analytic Hierarchy Process (AHP). It is used to reveal the priority of cyclists safety facilities in Surabaya based on the assessment given by the stakeholders as respondents. From the analysis of Analytic Hierarchy Process (AHP), the order of safety priorities for cyclists is based on five criteria such as socio-economic aspects, movement aspects, behavioral aspects, accident aspects, as well as geometric and traffic aspects. As an alternative choice, the respondents consider that law enforcement is the main priority of cyclists' safety facilities in Surabaya with a percentage of $24 \%$ followed by the handling of accident by $17 \%$, traffic order and road safety campaign by $13 \%$, speed limitation by $12 \%$, bicycle lane provision by $11 \%$, and cycling safety standard and compliance by $10 \%$.
\end{abstract}

\section{KEY WORDS}

Safety Priority, Surabaya Cyclists, Analytic Hierarchy Process (AHP).

The rapid development of transportation in Indonesia leads to an increasingly complex problem such as traffic congestion, air pollution, noise pollution, and a bigger number of accidents that occur on the highway. Traffic accidents not only involved fatalities or injuries but also enormous economic and social losses.

The heterogeneous traffic condition is one reason for the high number of accidents in Indonesia. Based on the data obtained from East Java Regional Police Department, the number of accidents in Surabaya has continued to increase in the last three years. It is shown that as many as 732 events of accidents occur in 2014 and increased to 870 cases in 2015 and to 1326 cases in 2016. 
One effort to reduce these existing problems is by implementing an environmentally sustainable transport that is by encouraging more effective, healthy, and eco-friendly transportation modes such as public transport and non-motorized vehicles like bicycles.

To get great benefits related to the use of the bicycle for more effective, healthy, ecofriendly, and safer transportation, it is necessary to prioritize the safety of cyclists based on the results of the study examining the factors that cause accidents.

\section{LITERATURE REVIEW}

Accident. Traffic accidents are unexpected and accidental involving vehicles with or without other road users resulting in human fatalities and/or property losses (Law number 22 of 2009). Broadly speaking, there are 5 factors related to traffic accidents such as a driver, passenger, road users, vehicles, and street facilities (Sulistio, 2008). Human as the driver has physiological and psychological factors. These factors need to be taken into account because they have the potential to cause an accident. Drivers' behavior came from the interaction between human factors with other factors including their relationship with vehicle elements and road environments (Dwiyogo dan Prabowo, 2006).

In this context, passengers can be defined as human or goods transported by a means of transportation. Passengers are capable to cause an accident if the goods transported exceeds the maximum capacity so that it interferes the performance of the vehicle. The occurrence of road accidents is usually caused by an imperfect geometric state of the road, holes, slippery road, and the flow of the traffics passing through it. Vehicles also become one of the causes because of the technical conditions that do not run properly like brake failure, engine strike, broke tires, and so on. Besides that, the exceeded maximum capacity of the load also makes the vehicle difficult to control.

Safety. Safety reflects a condition that is safe where there is a protection either on the physical components, damage, failure, error, or various undesirable conditions. In regard to the safety of cyclists, there are several things to note, including:

- Before using the bike.

Check the front and rear brakes, tires, lights, and chains.

- During the use.

Concentrate and quiet, do not drive with one hand. Look the conditions around when about to precede other vehicles. Obey the rules and traffic signs, and most importantly, realize the rights of other road users for mutual comfort and safety.

Safety Action Program. According to Sulistio (2008), this program is based on the priority of safety issues in each country which generally comes from the recommendation of in-depth study. The evaluation of effectiveness in each stage of the program implementation is done for the improvement of next program.

The action programs that can be done as a form of handling and improvement of cyclists' safety in Surabaya include the provision of bicycle lanes, cycling accidents campaign, law enforcement, post-accident handling, compliance and bicycle standards improvement, and speed limitation.

\section{METHODS OF RESEARCH}

In this study, experts or stakeholders come from the Department of Transportation, Directorate General of Bina Marga of Public Works Department, Police Department, and Education Department in Surabaya. There are 10 people as samples with the consideration that these respondents are people who really understand the safety priority of cyclists in Surabaya.

Descriptive Statistics Analysis. An analysis used to solve a problem by using the existing facts to describe the subject or object of the research either individually, in institutions, in society, and so forth. 
Eurasia: Economics \& Business, 6(12), June 2018

DOI https://doi.org/10.18551/econeurasia.2018-06

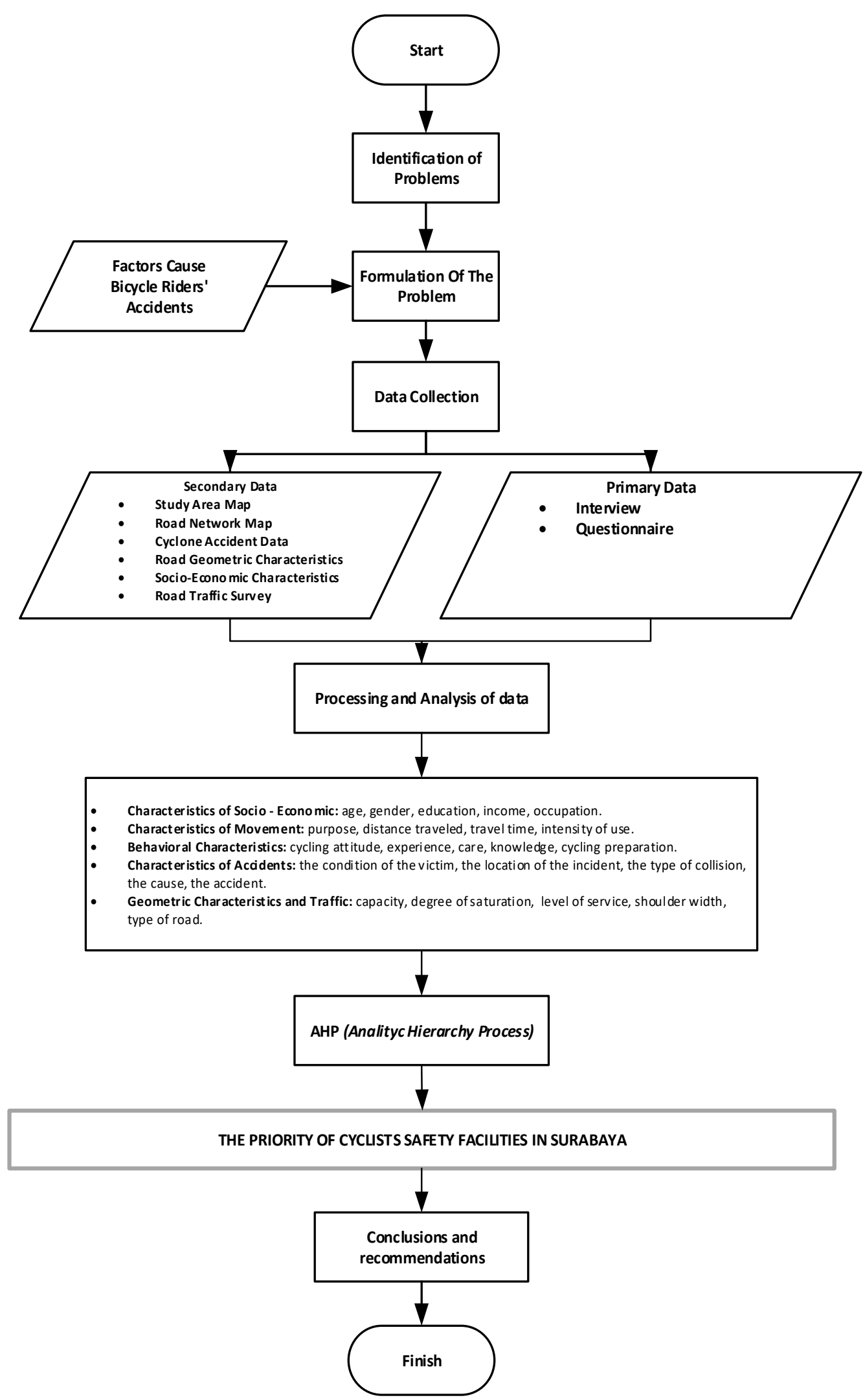

Figure 1 - Flow Chart of the Research

Analytic Hierarchy Process (AHP). AHP method is used to obtain the assessment or perception of stakeholders related to the safety priority of cyclists in Surabaya. The stages and formulas in AHP method are as follows: 
- Defining the problem and determining the desired solution.

- Creating a hierarchical structure that begins with general goals, criteria, subcriteria, and alternatives to be ranked.

- Giving weight to each criterion, sub-criteria, and alternative priorities by comparing one with the other.

- Defining the Consistency Ratio (CR) by:

Looking for Priority Vectors (w):

$$
=\frac{1}{n} \sum_{j=i}^{n} a(i, j)
$$

Looking for maximum consistency:

$$
\begin{aligned}
& \lambda_{\max }=\sum w x \text { Lawal matriks } \\
& \text { Consistency Ratio }=\frac{C I}{\mathrm{RI}}
\end{aligned}
$$

The results are said to be consistent and can be used if $\mathrm{CR} \leq 10 \%$. Calculating the priority of each alternative in each hierarchy or strata.

\section{RESULTS AND DISCUSSION}

Some steps that must be taken in analyzing the priority of cyclists' safety facilities in Surabaya by using AHP method are:

Determining the problem. To determine the alternative priority of cyclists' safety facilities in Surabaya, it is necessary to understand the factors related to cyclists' accidents in terms of socio-economic characteristics, movement characteristics, behavioral characteristics, accident characteristics, as well as geometric and traffic characteristics.

Assessing the weaknesses of the cause:

- Weak law enforcement;

- No or limited bike lanes;

- The lack of awareness of road users towards the rights of other road users especially non-motorized vehicles;

- The lack of several bicycles attributes such as lights and reflector so that it is unable to see other riders;

- The lack of knowledge about traffic safety aspects on the road.

Structuring the research hierarchy. It is used to simplify a problem so that it is easier to be understood. It is arranged on 3 levels, where level 0 : the research purpose which is to know the priority of cyclists' safety in Surabaya; level 1: the criteria consisting of 5 aspects such as socio-economy, behavior, movement, accidents, geometric and traffic; level 2: subcriteria that support the 5 aspects, as for an example, the socio-economic aspects which consist of age, sex, income level, occupation, and educational level; level 3: the alternative safety priorities for cyclists in Surabaya.

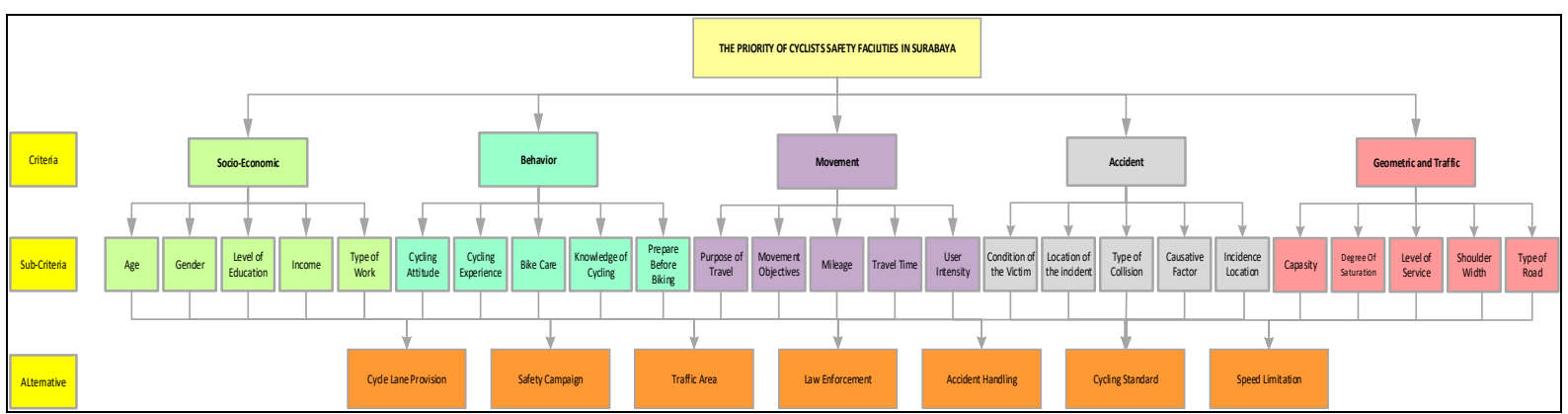

Figure 2 - The Hierarchy Structure of Cyclists' Safety Priority in Surabaya 
Selecting the Cyclists' Safety Facilities Priority. Due to the fact that the decision-makers or stakeholders are more than one person, a matrix of joint opinion is made where the elements of the new matrix are derived from the geometric average of individual opinion matrix elements whose value of inconsistency ratio is eligible.

Weighting the Comparison of Criteria (Level 1).

Level 1 weighting is a combined weighting of 10 stakeholders related to the assessment of the criteria aspects as shown in the following Table 1.

Based on Table 1, it is known that the value of consistency ratio (CR) of the joint criteria is $<0.1$ or $10 \%$. Thus, it can be said to be consistent. The results of stakeholder assessment related to the combined criteria aspects can be seen in Figure 5.1.

Table 1 - The weight of Combined Criteria

\begin{tabular}{|c|c|c|c|c|c|c|c|c|}
\hline Characteristic & Socio-Economic & Movement & Behavior & Accident & Geometric and Traffic & $\begin{array}{l}\text { Priority } \\
\text { Vector }\end{array}$ & $\lambda \max$ & \\
\hline Socio-Economic & 1.00 & 0.90 & 0.26 & 0.72 & 2.25 & 0.143 & 1.110 & \\
\hline Movement & 1.12 & 1.00 & 0.40 & 0.55 & 1.93 & 0.146 & 0.986 & \\
\hline Behavior & 3.81 & 2.52 & 1.00 & 1.43 & 4.74 & 0.394 & 1.013 & \\
\hline Accident & 1.38 & 1.81 & 0.70 & 1.00 & 3.18 & 0.242 & 0.973 & \\
\hline Geometric and Traffic & 0.44 & 0.52 & 0.21 & 0.31 & 1.00 & 0.074 & 0.972 & \\
\hline Total & 7.75 & 6.74 & 2.57 & 4.02 & 13.11 & 1.00 & $\lambda \max$ & 5.055 \\
\hline & & & & & & & $\begin{array}{l}\mathrm{Cl}= \\
\mathrm{CR}=\end{array}$ & $\begin{array}{l}0.014 \\
0.012\end{array}$ \\
\hline
\end{tabular}

Based on the level 1 hierarchy assessment towards the combined characteristics of each stakeholder, the highest priority is behavioral aspect by $39 \%$ and then accident aspect by $24 \%$, movement aspect by $15 \%$, and socioeconomic aspect by $14 \%$. The lowest priority is $8 \%$ which is the geometric and traffic aspect. This means that in regard to the alternatives of cyclists' safety priority in Surabaya, the aspect of behavior has a very big role compared to other aspects.

Weighting the Comparison of Sub-Criteria (Level 2). The calculation result is obtained by multiplying the weight of each criterion with each sub-criterion. The result of this level 2 weighting is shown in Table 2 below.

Table 2 - The weight of Combined Sub-Criteria

\begin{tabular}{|c|c|c|c|c|c|c|c|c|}
\hline \multirow{3}{*}{ Criteria } & \multirow{3}{*}{ Sub-Criteria } & \multirow{3}{*}{ Calculation of Level 2} & \multicolumn{5}{|c|}{ Nilai Bobot Kriteria } & \multirow{3}{*}{$\begin{array}{l}\text { Total Weight o } \\
\text { the Alternative }\end{array}$} \\
\hline & & & Socio-Economic & Behavior & Movement & Accident & Geometric and Traffic & \\
\hline & & & 0,143 & 0,146 & 0,394 & 0,242 & 0,074 & \\
\hline \multirow{5}{*}{ Socio-Economic } & Age & 0,365 & 0,052 & 0 & 0 & 0 & 0 & 0,052 \\
\hline & Gender & 0,203 & 0,029 & 0 & 0 & 0 & 0 & 0,029 \\
\hline & Level of Education & 0,170 & 0,024 & 0 & 0 & 0 & 0 & 0,024 \\
\hline & Income & 0,119 & 0,017 & 0 & 0 & 0 & 0 & 0,017 \\
\hline & Type of Work & 0,142 & 0,020 & 0 & 0 & 0 & 0 & 0,020 \\
\hline \multirow{5}{*}{ Movement } & Purpose of Travel & 0,326 & 0 & 0,048 & 0 & 0 & 0 & 0,048 \\
\hline & Movement Objectives & 0,093 & 0 & 0,014 & 0 & 0 & 0 & 0,014 \\
\hline & Mileage & 0,125 & 0 & 0,018 & 0 & 0 & 0 & 0,018 \\
\hline & Travel Time & 0,270 & 0 & 0,040 & 0 & 0 & 0 & 0,040 \\
\hline & User Intensity & 0,185 & 0 & 0,027 & 0 & 0 & 0 & 0,027 \\
\hline \multirow{5}{*}{ Behavior } & Cycling Attitude & 0,375 & 0 & 0 & 0,148 & 0 & 0 & 0,148 \\
\hline & Cycling Experience & 0,243 & 0 & 0 & 0,096 & 0 & 0 & 0,096 \\
\hline & Bike Care & 0,096 & 0 & 0 & 0,038 & 0 & 0 & 0,038 \\
\hline & Knowledge of Cycling & 0,207 & 0 & 0 & 0,082 & 0 & 0 & 0,082 \\
\hline & Prepare Before Biking & 0,079 & 0 & 0 & 0,031 & 0 & 0 & 0,031 \\
\hline \multirow{5}{*}{ Accident } & Condition of the Victil & 0,326 & 0 & 0 & 0 & 0,079 & 0 & 0,079 \\
\hline & Location of the incide & 0,093 & 0 & 0 & 0 & 0,023 & 0 & 0,023 \\
\hline & Type of Collision & 0,125 & 0 & 0 & 0 & 0,030 & 0 & 0,030 \\
\hline & Causative Factor & 0,270 & 0 & 0 & 0 & 0,065 & 0 & 0,065 \\
\hline & Incidence Location & 0,185 & 0 & 0 & 0 & 0,045 & 0 & 0,045 \\
\hline \multirow{5}{*}{ Geometric and Traffic } & Capasity & 0,218 & 0 & 0 & 0 & 0 & 0,016 & 0,016 \\
\hline & Degree of Saturation & 0,232 & 0 & 0 & 0 & 0 & 0,017 & 0,017 \\
\hline & Level of Service & 0,192 & 0 & 0 & 0 & 0 & 0,014 & 0,014 \\
\hline & Shoulder Width & 0,299 & 0 & 0 & 0 & 0 & 0,022 & 0,022 \\
\hline & Type of Road & 0,059 & 0 & 0 & 0 & 0 & 0,004 & 0,004 \\
\hline Jumla & & & & & & & & 1,000 \\
\hline
\end{tabular}

Based on the results of level 2 hierarchy assessment above, it is known that the highest priority is the sub-criteria of cycling attitude derived from behavioral criteria by $15 \%$, and then experience by $10 \%$, victim condition by $8 \%$, causative factor by $7 \%$, age by $5 \%$, 
travel intention by $5 \%$, treatment by $4 \%$, accident by $4 \%$, travel time by $4 \%$, cycling attitude by $3 \%$, accident type by $3 \%$, gender by $3 \%$, user intensity by $3 \%$, incidence location by $2 \%$, tiredness degree by $2 \%$, roadside area by $2 \%$, education level by $2 \%$, income by $2 \%$, job occupation by $2 \%$, distance by $2 \%$, service level by $1 \%$, and lastly, goal by $1 \%$.

Comparing the Alternative Safety Priority (Level 3). The weight calculation of cyclists' safety alternatives in Surabaya can be done by multiplying the priority vector from the calculation of combined criteria based on their characteristics as shown in Table 1 with the priority vector of the combined sub-criteria in Table 2 as well as the priority vector of each combined sub-criterion alternatives as we can see in Table 3.

Table 3 - Combined Weight of Cyclists' Safety Facilities

\begin{tabular}{|c|c|c|c|c|c|c|}
\hline \multirow{2}{*}{$\begin{array}{c}\text { Alternative Safety Action } \\
\text { Program }\end{array}$} & \multicolumn{5}{|c|}{ The weight of Alternative Safety Action Program } & \multirow{2}{*}{$\begin{array}{l}\text { Total Weight of } \\
\text { the Alternatives }\end{array}$} \\
\hline & Socio-economic & Movement & Behavior & Accident & Geometric and Traffic & \\
\hline Bicycle Lane Provision & 0.0164 & 0.0299 & 0.0319 & 0.0170 & 0.0170 & 0.1122 \\
\hline Safety Campaign & 0.0162 & 0.0193 & 0.0558 & 0.0241 & 0.0129 & 0.1282 \\
\hline Traffic Area & 0.0161 & 0.0185 & 0.0576 & 0.0337 & 0.0069 & 0.1329 \\
\hline Law Enforcement & 0.0415 & 0.0274 & 0.0938 & 0.0642 & 0.0139 & 0.2407 \\
\hline Accident Handling & 0.0254 & 0.0145 & 0.0679 & 0.0581 & 0.0045 & 0.1704 \\
\hline Cycling Standard & 0.0139 & 0.0184 & 0.0384 & 0.0175 & 0.0050 & 0.0932 \\
\hline Speed Limitation & 0.0138 & 0.0185 & 0.0486 & 0.0274 & 0.0140 & 0.1223 \\
\hline
\end{tabular}

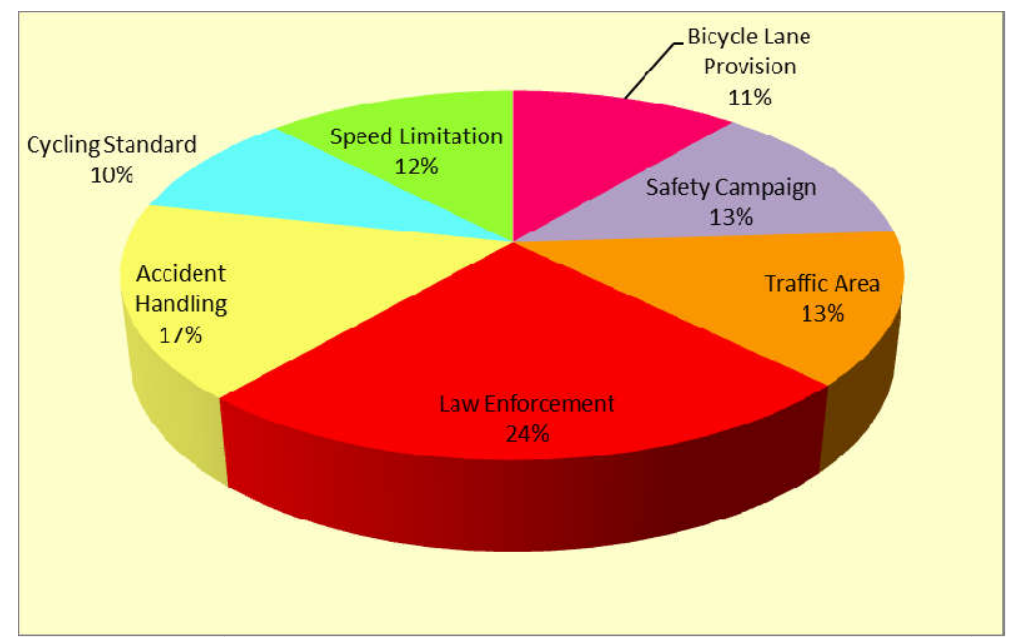

Figure 3 - Priority of Cyclists' Safety Facilities in Surabaya

Based on the level 3 hierarchy assessment towards the alternatives combination of each assessment, it is obtained that the highest priority of cyclists' safety facilities in Surabaya is law enforcement with a percentage of $24 \%$ and then followed by accident handling $(17 \%)$, traffic area and road safety campaign (13\%), speed limitation (12\%), bicycle lane provision (11\%), and cycling compliance and safety standard (10\%).

Strengthening the Selected Alternatives. Based on the analysis that has been given by the Analytic Hierarchy Process, law enforcement is considered to be the top priority in handling the safety of cyclists in Surabaya with a percentage of $24 \%$. Law enforcement can be done by giving a deterrent effect to those who violate the rules so that they will not commit the same violation again. In addition to that, it also needs to construct the law of cycling on the highway either about the completeness of the bike or the completeness of its users such as the requirement to use personal protective equipment and/or to use bright clothes.

\section{CONCLUSION}

Based on the result of Analytic Hierarchy Process calculation, the order of priority for cyclists' safety facilities which based on 5 criteria such as socio-economic aspect, movement aspect, behavioral aspect, accident aspect, as well as geometric and traffic aspect, the respondents consider that law enforcement is the main alternative to handle the safety of 
cyclists in Surabaya with a percentage of $24 \%$. Then, it is followed by accident handling by $17 \%$, traffic order and road safety campaign by $13 \%$, speed limitation by $12 \%$, the provision of bicycle lane by $11 \%$, and cycling compliance and safety standard by $10 \%$.

The decision makers or respondents in the future study should be the people who really understand the issues related to safety and comfort of bicycle users. This is due to the fact that AHP method really concerned about the assessment and consistency of the answers given by the respondents. Therefore, the results will be in accordance with the handling of the existing problems and can be applied to get great benefits in the field.

\section{REFERENCES}

1. Dwiyogo, P., \& Prabowo, R. H. (2006). Studi Identifikasi Daerah Rawan Kecelakaan (Black Spot Dan Blacksite) Pada Jalan Tol Jagorawi (Unpublished Thesis). Fakultas Teknik Undip, Semarang.

2. Sulistio, Harnen. (2008). Keselamatan Transportasi Jalan, Strategi, Kelembagaan, dan Program Aksi Dalam Pembentukan Transportasi Jalan. Malang: Universitas Brawijaya.

3. Polda Jatim. (2017). Data Kecelakaan Lalu Lintas Surabaya. Retrieved from http://korlantas.info

4. Republik Indonesia. (2009). Undang-Undang Republik Indonesia No.22 Tahun 2009 tentang Lalu Lintas dan Angkutan. 